\title{
The impact of David Paintin's work
}

\section{Kate Margaret Paterson}

BMJ SRH, London, UK

Correspondence to

Dr Kate Margaret Paterson, BMJSRH, London, UK; bmjsrh@ bmj.com
Check for updates

(C) Author(s) (or their employer(s)) 2019. No commercial re-use. See rights and permissions. Published by BMJ.

To cite: Paterson KM. BMJ Sex Reprod Health 2019;45:226.

\section{David Paintin, Hon FFSRH, MB ChB, FRCOG}

Emeritus Reader in Obstetrics and Gynaecology, University of London, London, UK

18 December 1930-30 March 2019

David Paintin believed that women should have equal status, rights and total control over their fertility. He spent his life working towards this end, committed to public service, and never practising privately. He was a remarkable obstetrician, gynaecologist and teacher with ideas ahead of his time.

David trained in Aberdeen where he was influenced by Professor Baird's work on the effects of social deprivation on maternal and child health, as well as the need for safe abortion. The Offences Against the Person Act of 1861 stated that abortions performed unlawfully could be prosecuted, but case law (such as the Aleck Bourne judgment in 1939) suggested that a woman's health could be taken into consideration. However, the lack of clarity meant practitioners of abortion remained at risk of prosecution.

David strongly supported the current movement to decriminalise abortion. When he arrived at St Mary's Hospital in London in the early 1960s, he continued to perform abortions, and joined the Abortion Law Reform Association (ALRA). This group was comprised of powerful campaigners from many walks of life who worked with parliamentarians to clarify the law. David was a medical advisor to both Lord Silkin, who first took the Abortion Act to Parliament, and later Lord Steel who introduced a private bill which succeeded in 1967. The team sought to produce a bill which made the law clear, as well as flexible, that would be acceptable to Parliament. At the time it was the most liberal abortion law in Europe, but has since been overtaken by many other countries.

Despite working as a full-time clinician and university lecturer, throughout his career and after his retirement he continued to monitor abortion law. The majority of attempts to reduce access to abortion or lower the legal gestational limit have been unsuccessful, but David made a statement in 1990 supporting an upper limit of 24 weeks, as the lowest realistic expectation of viability, even with the improvements in neonatal care since 1967. This intervention reduced the likelihood of an earlier upper limit being imposed. He continued to work to make abortion legal in Ireland.

David believed in the separation of abortion from routine gynaecology. In 1982 he set up a combined service with community family planning in West Kensington which covered assessment and counselling, the procedure itself and contraceptive follow-up. He was a trustee and chair of the Birth Control Trust (BCT), an organisation whose first objective was to advance sociological research in contraception, sterilisation and lawful termination of pregnancy. The BCT did much to encourage and support services to provide early medical abortion after the licensing of mifepristone in 1991.

He was appointed chair of the Royal College of Obstetricians and Gynaecologists (RCOG) working party on abortion for fetal abnormality, and held the post of editor at the British Journal of Obstetrics and Gynaecology (1988-1992).

Many activists, educators and abortion providers today have been inspired and influenced by David's ideas and work. $\mathrm{He}$ was concerned that people might become complacent about the Abortion Act 1967, and felt that all moves to limit women's right to choose an abortion should be carefully monitored and strongly resisted.

David has documented his abortion law reform experience in a personal account published by British Pregnancy Advisory Service (bpas) (http://www.abortionreview.org/images/uploads/Paintin_memoir. pdf).

Provenance and peer review Commissioned; internally peer reviewed. 